\title{
Analysis of Proteins Associated with Chinch Bug (Blissus leucopterus leucopterus Say)-Infested Corn (Zea mays L.) Seedlings
}

\author{
Sita R. Ghimire, Sonya M. Baird, Gerald T. Baker and Peter W.K. Ma*
}

Department of Entomology and Plant Pathology, P.O. Box 9775, Mississippi State University, Mississippi State, MS 39762, USA

\begin{abstract}
A proteomics approach was used to study the proteins associated with chinch bug infested corn seedlings. Examination of two-dimensional gels revealed the presence of more than 600 high quality protein spots each from chinch bug-infested and healthy corn seedlings. A total of 31 protein spots was selected for matrix-assisted laser desorption and ionization time-of-flight mass spectrometric analysis. Among the protein spots selected, 13 were from infested plants, 10 from healthy plants, and four each from healthy and infested plants having differential expressions. Peptide mass fingerprinting revealed that each spot analyzed represents a different protein. Thirty-nine percent of the proteins had confirmed identity and the rest were tentatively identified. Among 13 proteins analyzed from infested seedlings most were related to defense, cell rescue, virulence and metabolism. Some of these proteins related to metabolism and protein synthesis were down-regulated in the infested seedlings. All proteins except one from infested corn seedlings seem to be activated in the plant system because of the chinch bug-induced stresses including osmotic, oxidative and acid stresses, and wounding.
\end{abstract}

Key Words: Goose-necking, peptide mass fingerprinting, post-translational modification, protein extraction.

\section{INTRODUCTION}

The common chinch bug, Blissus leucopterus leucopterus (Say) is an important early season pest of corn, Zea mays L., in the southeastern United States [1]. Chinch bug nymphs and adults have piercing and sucking mouthparts and can cause serious damage to corn crops. Adults and nymphs suck plant sap from the base of the stem and roots of the seedlings causing wilting, stunting, and sometimes death of the plants. Feeding on and attack at the early developmental stages of corn may lead to a severe deformation of corn seedlings referred as 'goose-necking' and characterized by abnormally long whorl with tightly furled leaves [1]. Goose-necking is terminally detrimental to the seedlings as they do not reach maturity and often break apart in the curved stalk area. The level of crop damage and associated yield losses depends on the insect populations and growth stage of the crop at the time of the infestation. Seedlings are more sensitive to insect damage than older plants [2]. The current chinch bug management strategies are early planting of corn and preventive or rescue applications of insecticides [1]. Early planting is not always feasible because of inclement weather conditions. Similarly, the insecticides are costly and sometimes ineffective because of difficulties in getting the insecticides to the chinch bug feeding sites. Moreover, the growing concerns of public health and environmental impacts have limited the use of some insecticides. Therefore, both planting date adjustment and pesticide-based management strategies are often not practical. In this context the utilization of host resistance

*Address correspondence to this author at the Department of Entomology and Plant Pathology, P.O. Box 9775, Mississippi State University, Mississippi State, MS 39762, USA; Tel: 662325 2978; Fax: 6623258837 ; E-mail.pma@entomology.msstate.edu seems very promising. The presence of different levels of resistance in corn varieties to chinch bug attack has been reported $[1,3,4]$ but no report is available as to the presence of desired levels of resistance to chinch bug in any commercially cultivated corn varieties.

Abnormal appearance of corn seedlings upon chinch bug infestation is a complex phenomenon which may be attributed to several factors. As the insect pierces the plant cells and tissues and sucks plant sap, the mechanical damage to the plant cells and tissues and the depletion of nutrients from the plant system could be important factors responsible for an abnormal appearance. The possible roles of some chemical factor (s) of insect origin injected into the plant system during the infestation process and their interactions with host factor(s) might have also some importance in this complex phenomenon. This study aims (1) to investigate and compare proteomes from chinch bug-infested and healthy corn seedlings, and (2) to analyze new and differentially-expressed proteins from both systems on a functional basis. This study will elucidate the biological basis of abnormal appearance of corn seedlings. Such information would be useful in devise appropriate pest management strategies.

\section{MATERIALS AND METHODOLOGY}

\section{Chemicals}

Chemicals trichloroacetic acid (TCA) and $\alpha$-cyano-4hydroxycinnamic acid (CHCA) were purchased from SigmaAldrich Chemical Company (St. Louis, MO, USA) and sodium dodecyl sulfate (SDS) was obtained from Fischer Scientific Company (Fairfield, NJ, USA). Other chemicals such as Pharamalyte, 3-[(3-Cholamidopropyl)-dimethylammonio]- 
1-propane sulfonate (CHAPS) and dithiothreitol (DTT) were purchased from GE Health Care (Piscataway, NJ, USA) whereas ethylene-diamine-tetra-acetic acid (EDTA) was obtained from Polysciences (Warrington, PA, USA).

\section{Insects}

Chinch bugs, Blissus leucopterus leucopterus (Say), were collected in the $500 \mathrm{ml}$ polypropylene jars from R. R. Foil Plant Science Research Center at Mississippi State University. Insects were then transferred into the clear plastic tote (24-1/4"L X 17-1/4"W X 15"H) containing pre-grown young corn seedlings. The top of the tote was tightly covered with muslin cloth to prevent the bugs from escaping. Chinch bugs in the clear tote were maintained in the growth chamber at 32 ${ }^{\circ} \mathrm{C}$ and $75 \%$ relative humidity with a light and dark cycle of $16 / 8 \mathrm{hr}$, respectively, until they were used for the infestation study.

\section{Plant Materials}

Corn (Zea mays L.) seeds of the cultivar Trucker's Favorite White were planted (two seeds per pot) in $15 \mathrm{~cm} \mathrm{di-}$ ameter plastic pots with drainage holes. Plants were watered as needed through pot bottoms. Three to four days after emergence, the plants were thinned to one plant per pot. Plants were maintained in the growth chamber under fluorescent light (6000 lx, $16 \mathrm{~h}$ light period per day) at $75 \%$ relative humidity and $32^{\circ} \mathrm{C}$. Seven to ten day old seedlings of $\mathrm{V}_{2-3}$ leaf stages as described previously [5], were infested with twelve chinch bugs per seedling for seven days. Healthy plants were grown in the same environment without chinch bug infestation. Deformed seedlings were harvested on the seventh day post infestation along with the healthy seedlings. Above ground plant tissues were weighed, labeled and stored at $-80^{\circ} \mathrm{C}$ until further processing.

\section{Protein Extraction}

Total protein was extracted according to the method of Hurkman and Tanaka [6]. Briefly, one gram of lyophilized plant tissue was pulverized in liquid nitrogen, and suspended in to $2.5 \mathrm{ml}$ of extraction buffer $[0.7 \mathrm{M}$ sucrose, $0.5 \mathrm{M}$ Tris $(\mathrm{pH} 8.5), 0.05 \mathrm{M}$ EDTA, $0.1 \mathrm{M} \mathrm{KCl}$ and $2 \%(\mathrm{v} / \mathrm{v}) 2-$ mercaptoethanol] and incubated for $10-15 \mathrm{~min}$ at $4^{\circ} \mathrm{C}$. An equal volume of water-saturated phenol was added, and the mixture was incubated for $10 \mathrm{~min}$ on a shaker at room temperature followed by centrifugation at $5000 \mathrm{Xg}$ for $10 \mathrm{~min}$. The organic phase was recovered and re-extracted with an equal volume of extraction buffer. Proteins were precipitated from the organic phase by the addition of five volume of a methanol solution $\left[0.1 \mathrm{M} \mathrm{NH} \mathrm{NH}_{4} \mathrm{Ac}\right.$ in methanol and $1 \%(\mathrm{v} / \mathrm{v})$ 2-mercaptoethanol] and incubated at $-20^{\circ} \mathrm{C}$ overnight. The precipitate was washed three times each with methanol solution and acetone $(80 \%)$. The pellet was dried and stored at $20^{\circ} \mathrm{C}$.

\section{Protein Solubilization and Quantification}

The protein pellet was suspended in a rehydration buffer [7M urea, 2M thio-urea, 4\% (w/v) CHAPS, 1\% (w/v) DTT and $2 \%(\mathrm{v} / \mathrm{v})$ Pharmalyte $\mathrm{pH} 3-10]$. The suspension was sonicated at $18-20^{\circ} \mathrm{C}$ for $30 \mathrm{~min}$ and centrifuged at 190,000Xg for $30 \mathrm{~min}$ in a Beckman Airfuge Ultracentrifuge (Beckman Coulter Inc, Fullerton, CA, USA). Protein con- centration was measured using the 2D Quant kit (GE Health Care, Piscataway, NJ, USA).

\section{IEF and SDS-PAGE}

Twenty-four centimeter-long immobilized $\mathrm{pH}$ gradient (IPG) strips with the $\mathrm{pH}$ range of 4 to 7 from the Bio-Rad (Hercules, CA, USA) were rehydrated in $400 \mu 1$ rehydration buffer containing approximately $2 \mathrm{mg}$ protein in an IEF Protean Cell (Bio-Rad) for $12 \mathrm{hrs}$ at $50 \mathrm{~V}$ and $23^{\circ} \mathrm{C}$. The voltage was programmed to increase linearly from 0 to $500 \mathrm{~V}$ over the period of one hour followed by $500 \mathrm{~V}$ to $10,000 \mathrm{~V}$ over the period of $5 \mathrm{~h}$ and then held at $10,000 \mathrm{~V}$ for a total of 100 $\mathrm{kVh}$. After focusing, the IPG strips were incubated with $1 \%$ DTT (w/v) in $10 \mathrm{ml}$ equilibration buffer [6 M Urea, 30\% (w/v) glycerol, $2 \%(\mathrm{w} / \mathrm{v}) \mathrm{SDS}, 50 \mathrm{mM}$ Tris- $\mathrm{HCl}(\mathrm{pH} 8.8)$ and $0.002 \%(\mathrm{w} / \mathrm{v})$ bromophenol blue] for $15 \mathrm{~min}$ and alkylated with $2.5 \%(\mathrm{w} / \mathrm{v})$ iodoacetamide in $10 \mathrm{ml}$ of equilibration buffer for $15 \mathrm{~min}$. Equilibrated strips were transferred to $12.5 \%$ polyacrylamide gel electrophoresis (SDS-PAGE) gels for second dimension electrophoresis in an Ettan Dalt-six gel system (GE Healthcare, Piscataway, NJ, USA). Electrophoresis was performed using $0.1 \%$ SDS electrophoresis buffer (25 mM Tris- $\mathrm{HCl}, 192 \mathrm{mM}$ glycine and $0.1 \%$ (w/v) SDS] in the lower chamber and $0.2 \%$ SDS electrophoresis buffer in the upper chamber at $100 \mathrm{~V}$ for $12-14 \mathrm{hr}$.

\section{Image Acquisition and Analysis}

After the second dimension electrophoresis, gels were stained using hot Coomassie brilliant blue [7], and destained with a solution containing $10 \%$ acetic acid and $30 \%$ methanol. Gel images were captured using a Versa Doc 3000 multi-imager (Bio-Rad) and analyzed with PDQuest 2D analysis software (Bio-Rad). The protein expression patterns in the gels from healthy and infested plants were also visually analyzed, and the protein spot, which were present in one group of gels and absent in another group and those having distinct differential expression patterns were selected for further analysis.

\section{MS Analysis and Peptide Mass Fingerprinting and Pro- tein Identification}

Protein spots of interest were manually excised with OneTouch Spot Pickers (Gel Company, San Francisco, USA). Excised protein spots were subjected to trypsin digestion using an In-Gel Tryptic Digestion Kit (PIERCE, Rockford, IL, USA) following the manufacturer's instructions. After digestion, the reaction mixture was desalted with $\mathrm{C}_{18} \mathrm{MB}$ pipette tips (Varian, Palo Alto, CA, USA), according to the manufacturer's instructions. Peptides were eluted in a volume of $2 \mu \mathrm{l}$ using $50 \%$ (v/v) acetonitrile containing $0.1 \%$ TFA. Peptides were mixed with an equal volume of matrix solution [ $\alpha$-CHCA saturated with $50 \%(\mathrm{v} / \mathrm{v})$ acetonitrile containing $0.3 \%$ TFA] and deposited onto the matrix assisted laser desorption ionization (MALDI) target plate. Peptide masses were measured using a Voyager Elite MALDITOF/MS (Applied Biosystems, Framingham, MA, USA) in positive reflectron mode at a maximum accelerating potential of $20 \mathrm{kV}$. The peptide mass fingerprints were processed manually to exclude the non-target fragments originated from matrix and trypsin autolysis. Edited peptide masses were used to identify the protein on SwissProt database 
(http://www.matrixscience.com) using MASCOT search engine software (Matrix Science, London, UK). A significant Mowse score at $95 \%$ confidence level, maximum peptide coverage and experimental confirmation of $\mathrm{M}_{\mathrm{r}}$ and $\mathrm{p} I$ values of the protein were considered as a reliable identification.

\section{RESULTS AND DISCUSSION}

\section{Comparison of Two Dimensional Protein Maps}

Protein maps for this study were derived using IPG strips with $\mathrm{pH}$ range of 4 to 7 . The selection of this $\mathrm{pH}$ range was based on the results of our preliminary study, which revealed that more than $95 \%$ of the soluble proteins in corn cultivar, Trucker's Favorite White, had an isoelectric point in the range of $\mathrm{pH} 4$ to 7 (data not shown). Previous studies with other corn lines had reported the majority of corn proteins having an isoelectric point in this $\mathrm{pH}$ range $[8,9]$. The protein maps for the chinch bug-infested and healthy corn seedlings are presented in the Figs. (1 and 2), respectively. Protein expression patterns in 2-D gels of chinch bug-infested and healthy corn seedlings were generally similar. Approximately 600 discrete protein spots were detected from both sample categories. The PDQuest analysis followed by visual comparison of the gels (three gels from each category) re- vealed that 10 protein spots were detected only in healthy seedlings; 13 were detected only in infested seedlings, and four proteins each were up-regulated or down-regulated in the infested seedlings (Figs. 1 and 2). This result is in agreement with a previous study, which noted the changes in the protein expression in wheat seedlings upon aphid infestation without visible changes in the infested seedlings [10]. Presence and absence of proteins and their differential expression were the common phenomenon when plants were exposed to stresses such as oxidative stress, salt stress and drought stress [9, 11-13]. A total of 31 protein spots having consistent presence or absence in at least two of three gels were selected for peptide mass fingerprinting. These proteins had molecular weights between 6 and $64 \mathrm{kDa}$. However, proteins having molecular weights of $4 \mathrm{kDa}$ to as high as 200 $\mathrm{kDa}$ were also observed in 2-D gels from both sample categories.

\section{Peptide Mass Fingerprinting and Protein Identification}

All thirty-one purposefully selected protein spots resulted in good quality, reproducible peptide mass fingerprints. Homology searches for the peptides from the protein spots revealed that each spot represents a separate protein; their detail is presented in the Table 1. Eighteen proteins had 6 to 15 matching peptides, 19 to $45 \%$ sequence coverage, and sig-

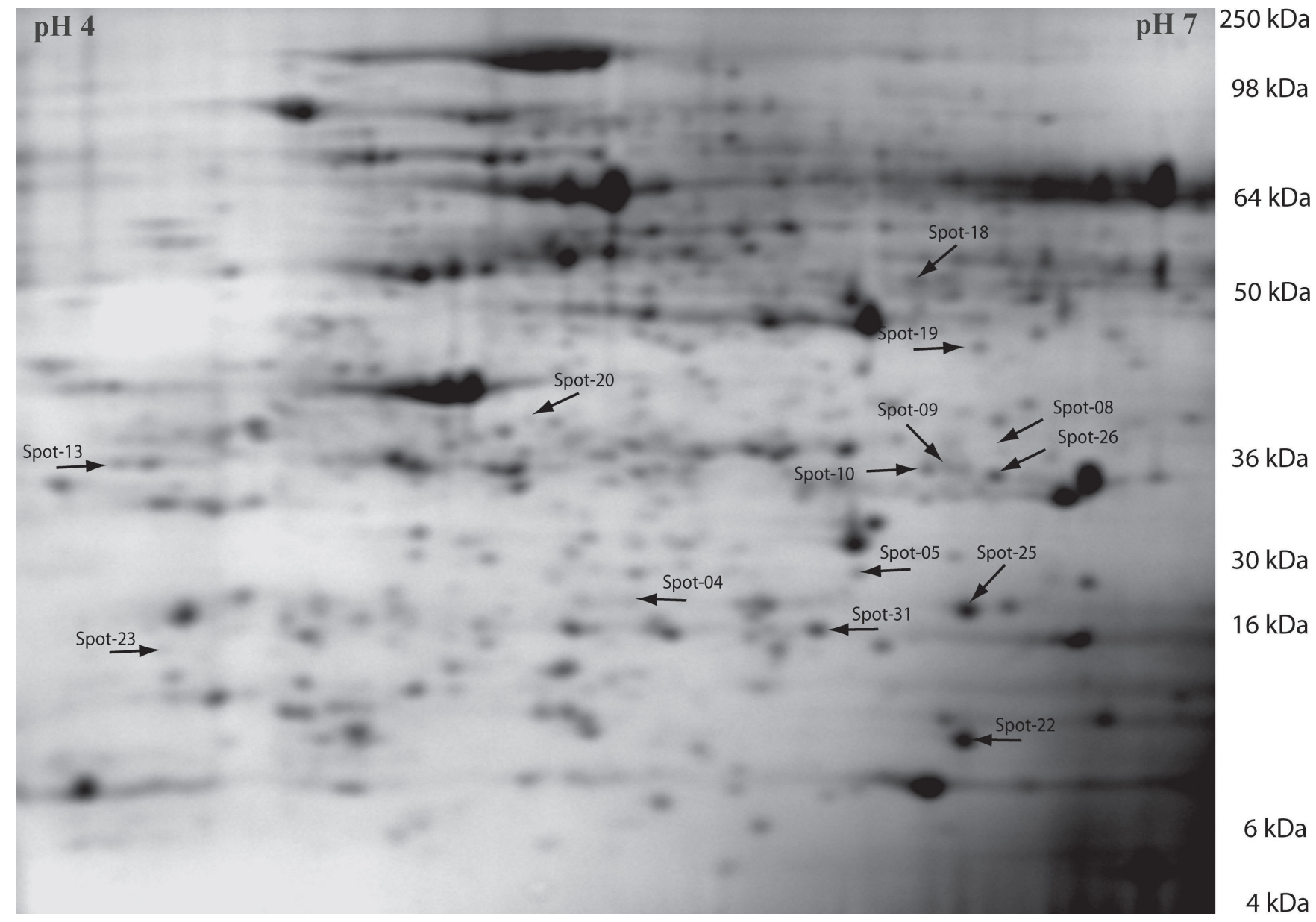

Fig. (1). Coomassie-stained 2-D protein map of chinch bug-infested maize seedlings showing the position of the selected protein spots for mass spectrometric analysis. 


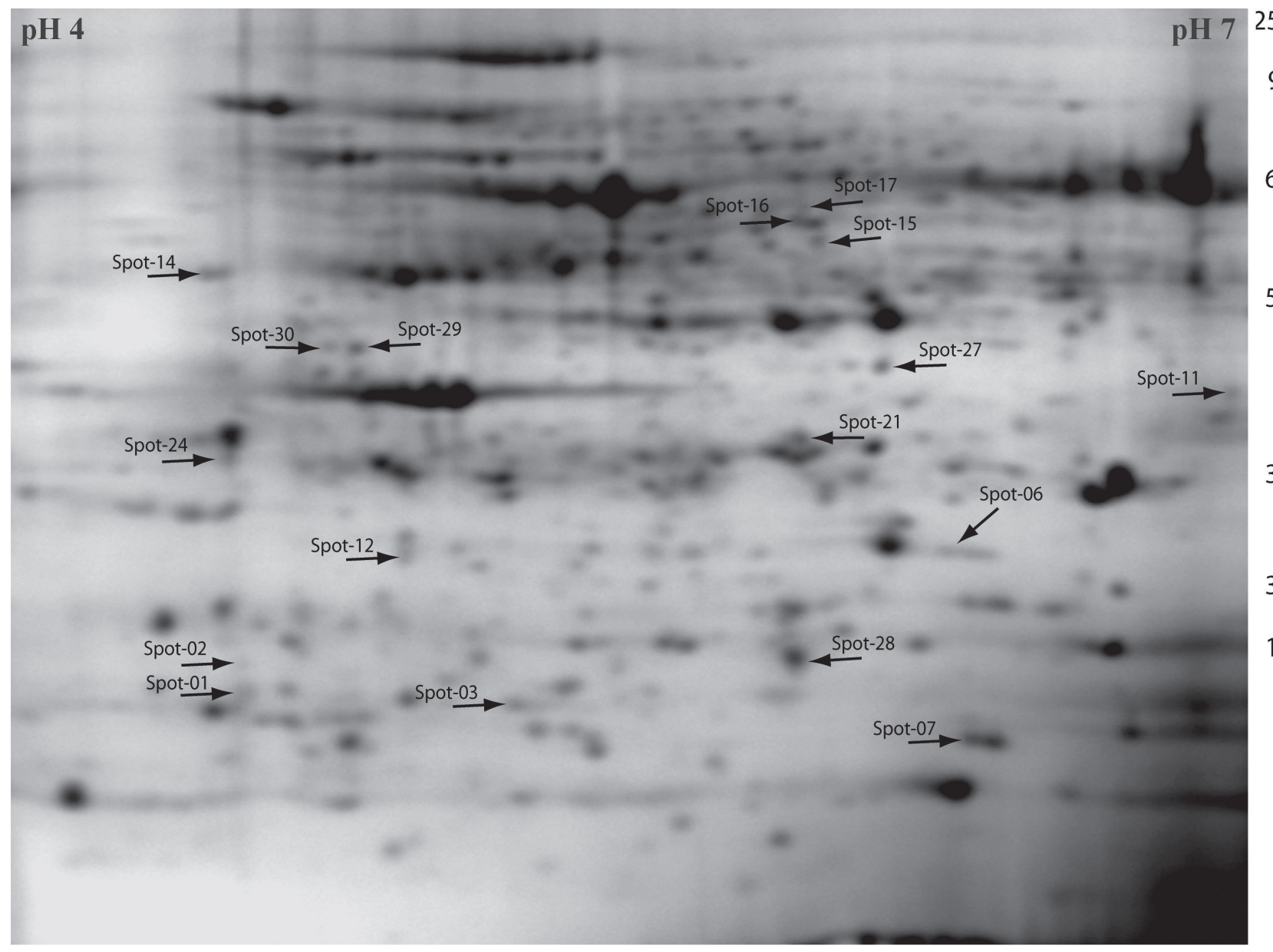

$250 \mathrm{kDa}$

98 kDa

$64 \mathrm{kDa}$

$50 \mathrm{kDa}$

$36 \mathrm{kDa}$

$30 \mathrm{kDa}$

$16 \mathrm{kDa}$

$6 \mathrm{kDa}$

Fig. (2). Coomassie-stained 2-D protein map of healthy maize seedlings showing the position of the selected protein spots for mass spectrometric analysis.

nificant Mowse scores at $95 \%$ confidence level. The other 13 proteins had 6 to 12 matching peptides, 9 to $29 \%$ sequence coverage, and a non-significant Mowse score ( $\mathrm{p}>0.05)$. Proteins having a significant Mowse score $(\geq 53)$ with closer experimental $M r$ and/or $p I$ values to theoretical values were considered reliably identified. In this experiment about $39 \%$ proteins were reliably matched. The other proteins had nonsignificant Mowse scores and there was a difference between experimental and/or theoretical values for either $M r, p I$ or both. Such differences in the experimental and theoretical values could have been the result of post-translational modification of proteins $[14,15]$. Seven of the thirty-one proteins had approximately three times higher theoretical $M r$ than their corresponding experimental $M r$. This situation might be the combined effect of post-translational modifications and protein fragmentation during the protein purification and subsequent down-stream application processes.

\section{Functional Analysis of Proteins}

Chinch bug infestations cause abnormalities in the corn seedlings such as stunting, wilting, goose-necking, and sometimes the death of the seedlings. Therefore the proteins from healthy and infested corn seedlings with confirmed and tentative identities were categorized at the functional level. A scheme of identified proteins according to their biological functions is presented in Fig. (3). As some proteins have been associated with more than one function, a single protein can be placed into different functional groups. Of the 31 proteins with confirmed and tentatively-confirmed identity, 10 proteins were involved in metabolism (biosynthesis of amino acids, flavonoids and carbohydrates, nitrate assimilation, lipid hydrolysis and reversal hydration of carbon dioxide), five in cell rescue, defense and virulence (conversion of monodehydroascorbate, conjugation of reduced glutathione, pest resistance and senescence or response to wounding, molecular chaperon), three in protein fate (recognition, assembly, translocation and folding), three in structural and binding function, two in energy production (manganese stabilization and ATP production), and other two proteins were involved in cellular fate (senescence, cell division and growth). Similarly, each protein was involved in transcription, cellular communication (phosphatidic acid accumulation upon dehydration stress), storage (somatic storage), cellular transport (mitochondrial protein import and macromolecular assembly), development, cell cycle and DNA processing, and interaction with the environment (disease resistance). One protein identified was a hypothetical protein at1g22800 with an unknown function. For convenience in the presentation of results, 31 proteins identified in this work are categorized into one of three different groups as: (i) those 
Table 1. Properties of Proteins from Chinch Bug Infested and Healthy Corn Seedlings

\begin{tabular}{|c|c|c|c|c|c|c|c|c|c|}
\hline \multirow{2}{*}{$\begin{array}{l}\text { Spot } \\
\text { No. }\end{array}$} & \multicolumn{2}{|r|}{ Protein } & \multirow{2}{*}{$\begin{array}{l}\text { Mowse } \\
\text { Score }\end{array}$} & \multirow{2}{*}{$\begin{array}{c}\text { Coverage } \\
(\%)\end{array}$} & \multicolumn{2}{|c|}{ pI } & \multicolumn{2}{|c|}{ MW (kDa) } & \multirow{2}{*}{$\begin{array}{l}\text { Sample } \\
\text { Source }\end{array}$} \\
\hline & Acc. No. & Name & & & Theo. & Exp. & Theo. & Exp. & \\
\hline 1 & Q9MUVO & RNA polymerase alpha subunit & 56 & 35 & 5.4 & 4.6 & 35.3 & 14.0 & I \\
\hline 2 & O49079 & Oxygen evolving enhancer protein 1 & 57 & 20 & 6.3 & 4.6 & 34.8 & 15.0 & I \\
\hline 4 & P41088 & Chalcone-flavonone isomerase & 72 & 45 & 5.3 & 5.4 & 26.6 & 30.0 & $\mathrm{H}$ \\
\hline 5 & P46422 & Glutathione S-transferase PM24 & 48 & 20 & 5.9 & 5.8 & 24.0 & 31.0 & $\mathrm{H}$ \\
\hline 6 & Q9C5Y0 & Phospholipase D Delta & 45 & 16 & 6.7 & 6.1 & 97.7 & 31.5 & I \\
\hline 9 & P10743 & Stem $31 \mathrm{kDa}$ glycoprotein & 48 & 29 & 6.7 & 6.1 & 29.3 & 35.5 & $\mathrm{H}$ \\
\hline 10 & P39871 & Nitrate reductase NADPH & 58 & 30 & 6.2 & 6.1 & 39.9 & 35.0 & $\mathrm{H}$ \\
\hline 11 & Q96558 & UDP-glucose-6-dehydrogenase & 57 & 19 & 5.7 & 6.6 & 52.9 & 41.5 & I \\
\hline 12 & Q43497 & Monodehydroascorbate reductase & 65 & 31 & 5.8 & 4.8 & 47.0 & 32.0 & I \\
\hline 13 & P93527 & Phytochrome B & 40 & 13 & 5.7 & 4.3 & 129.1 & 36.0 & $\mathrm{H}$ \\
\hline 14 & P92792 & Mitochondrial import receptor subunit TOM20 & 58 & 37 & 5.3 & 4.5 & 22.8 & 53.5 & I \\
\hline 15 & O80543 & Hypothetical protein at $1 \mathrm{~g} 22800$ & 54 & 23 & 5.1 & 5.8 & 39.9 & 57.0 & I \\
\hline 20 & Q43831 & RuBisCO binding protein beta subunit & 52 & 21 & 4.9 & 5.2 & 53.4 & 36.0 & $\mathrm{H}$ \\
\hline 21 & Q9FNF2 & Starch synthase, chloroplast & 38 & 15 & 6.0 & 5.8 & 72.1 & 36.0 & I -UR \\
\hline 22 & P27140 & Carbonic anhydrase & 82 & 42 & 5.5 & 6.1 & 29.5 & 11.0 & I-DR \\
\hline 23 & P54774 & Cell division cycle protein 48 homolog & 29 & 9 & 5.2 & 4.3 & 89.7 & 14.0 & I-DR \\
\hline 24 & Q09011 & Calcium binding protein (CAST) & 55 & 35 & 4.6 & 4.5 & 22.6 & 35.0 & I-UR \\
\hline 25 & P92981 & 5 '-adenyllylsulfate reductase 2 , chloroplast & 68 & 33 & 6.5 & 6.1 & 50.6 & 23.0 & I-DR \\
\hline 26 & P80608 & Cysteine synthase & 71 & 28 & 5.9 & 6.2 & 34.2 & 34.5 & I-DR \\
\hline 27 & P46750 & Protein disulfide-isomerase & 45 & 17 & 5.2 & 5.9 & 57.1 & 43.5 & I-UR \\
\hline 28 & Q9FVT2 & Probable elongation factor 1-gamma 2 & 57 & 21 & 5.6 & 5.7 & 46.4 & 15.0 & I-UR \\
\hline 29 & Q9SN58 & Probable UDP-glucose 4-epimerase At4g10960 & 64 & 25 & 5.5 & 4.8 & 38.5 & 43.5 & I-UR \\
\hline 30 & Q08277 & Heat shock protein 82 & 32 & 14 & 5.0 & 4.8 & 81.8 & 43.5 & I \\
\hline 31 & P80639 & Eukaryotic translation initiation factor $5 \mathrm{~A}$ & 55 & 27 & 5.6 & 5.8 & 17.5 & 16.0 & I-UR \\
\hline
\end{tabular}

Note: Proteins with Mowse score of 53 or higher are considered reliably identified. Letters I and H denote chinch bug infested and healthy corn seedlings, respectively, while UR and DR denote up-regulation and down-regulation of the corresponding protein in the infested seedlings. 
TRANSCRIPTION, PROTEIN SYNTHEIS, STORGAE, BINDING AND FATE

\begin{tabular}{|lll|}
\hline Q9MUVO & Q40147 & P93527 \\
P80639 & P92792 & Q43298 \\
P46750 & P10743 & Q43831 \\
Q09011 & Q9FVT4 & \\
\hline
\end{tabular}

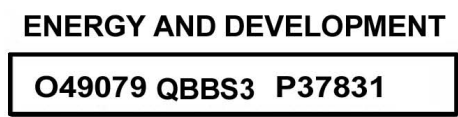

\begin{tabular}{|ll|}
\multicolumn{3}{c}{ METABOLISM } \\
\begin{tabular}{|lll|}
\hline P41088 & Q9C5YO Q9SZ30 \\
P39871 & Q96558 Q9FNF2 \\
P27140 & P92981 & P80608 \\
Q9SN58 & & \\
\hline
\end{tabular}
\end{tabular}

\section{DEFENSE AND INTERACTION}

\section{Q9SR59 P46422 Q43497}

P37831 Q08277 Q9LVT4

Fig. (3). Schematic presentation of identified proteins based on their biological functions (protein accession numbers are used for this presentation).

from infested seedlings only, (ii) those from healthy seedlings only, and (iii) those present in both sample categories but having differential expression levels or relative abundance. The role of these proteins in the abnormal appearance of chinch bug-infested corn seedlings will be discussed in the following sections as appropriate.

\section{Proteins from Chinch Bug-Infested Corn Seedlings}

Proteins associated exclusively with the chinch buginfested seedlings are presented with their possible functions in the Table 2. These proteins were responsible for transcription $(n=1)$, energy production $(n=2)$, cell rescue, defense and virulence $(n=3)$, metabolism $(n=2)$, metabolism and cellular communications $(n=1)$, protein fate $(n=1)$, protein fate and cellular transport $(n=1)$, protein binding $(n=1)$ and an unknown function $(\mathrm{n}=1)$.

The DNA-directed RNA polymerase alpha chain sub unit (spot 1 ) is a product of gene rpoA, which catalyzes the tran- scription of DNA into RNA. As this gene has been reported to be associated with the expression of some virulence genes within Agrobacterium tumefaciens [16], it might have a role in the expression of virulence gene(s) of chinch bug origin in the plant system. The oxygen evolving enhancer protein (spot 2) is encoded by the gene $p s b O$, and it is essential for an efficient and stable oxygen evolution, and is present in higher plants, green algae and cyanobacteria [17, 18]. It appears to play a major role in the stabilization of manganese cluster, probably by protecting it from endogenous reductants [19]. The possible roles of the photosystem II, and more specifically of $p s b O$ in constituting a basal defense mechanism against biotic stress, i.e. viral infection, have been proposed previously [20]. Monodehydroascorbate reductase (spots 3 and 12) is a key enzyme in maintaining reduced pools of ascorbate by reducing monodehydroascorbate to ascorbate, oxidizing NADP in the process. The ascorbate is a major antioxidant in the plant cell and it can act as a direct free radicals scavenger [21] or as an electron donor to

Table 2. Proteins from Chinch Bug-Infested Corn Seedlings with Putative Functions

\begin{tabular}{|c|c|c|c|}
\hline Spot No. & Accession No. & Protein Name & Function \\
\hline 1 & Q9MUVO & DNA directed RNA polymerase alpha chain & Transcription \\
\hline 2 & O49079 & Oxygen evolving enhancer protein & Energy production \\
\hline 3 & Q9SR59 & Probable monodehydroascorbate reductase & Cell rescue, defense and virulence \\
\hline 6 & Q9C5Y0 & Phospholipase D delta & Metabolism and cellular communications \\
\hline 7 & Q9SZ30 & Imidazole glycerol phosphate synthase & Metabolism \\
\hline 11 & Q96558 & UDP glucose 6 dehydrogenase & Metabolism \\
\hline 12 & Q43497 & Monodehydroascorbate reductase & Cell rescue, defense and virulence \\
\hline 14 & P92792 & Mitochondrial import receptor subunit & Protein fate \\
\hline 15 & O8043 & Hypothetical protein At1g22800 & Unknown \\
\hline 16 & QBBS3 & ATP synthase alpha chain & Energy production \\
\hline 17 & Q43298 & Chaperonin CPN 60-2 & Protein fate and cellular transport \\
\hline 24 & Q09011 & Calcium binding protein & Protein with binding function \\
\hline 30 & Q08277 & Heat shock protein 82 & Cell rescue, defense and virulence \\
\hline
\end{tabular}


ascorbate peroxidase for scavenging hydrogen peroxide involved in the ascorbate-glutathione cycle [22, 23]. Phospholipase D delta (spot 6) may be involved in phosphatidic acid accumulation in the dehydration stress responses and in the transduction of the hormonal and environmental signals to the microtubule cytoskeleton [24]. The production of phospholipase $\mathrm{D}$ delta in infested plant tissue could be the result of the depletion of plant sap by chinch bugs. Imidazole glycerol phosphate synthase (spot 7) is a member of the glutamine amidotransferase family and links histidine and de novo purine biosynthesis. The amido group of glutamine is transferred to a large variety of acceptor substrates by glutamine amidotransferase during the synthesis of various biomolecules including amino acids, nucleotides and coenzymes [25, 26]. The UDP-glucose 6-dehydrogenase (spot 11) belongs to the UDP-glucose/mannose dehydrogenase family and provides UDP glucuronic acid for hemicellulose precursors [27]. Mitochondrial import receptor subunit TOM20 (spot 14) functions as central component of the receptor complex responsible for the recognition and translocation of cytosolically synthesized mitochondrial protein. ATP synthase alpha chain (spot 16) is essential in producing ATP from ADP in the presence of a proton gradient across the membrane. Chaperonin CPN60-2, mitochondrial precursor (spot 17) is responsible for mitochondrial protein import and macromolecular assembly. It may also prevent misfolding and promote the refolding and proper assembly of unfolded polypeptides generated under stress conditions in the mitochondrial matrix. The calcium binding protein (spot 24) probably binds calcium ions. Calcium acts as a second messenger in many higher plant cellular activities such as cell elongation, cell division, protoplasmic streaming, and enzyme secretion. The HSP82 (spot 30) is one of the most highly conserved and abundantly synthesized heat shock proteins in the eukaryotic cells. Cells and tissues from a wide variety of organisms synthesize heat shock proteins when exposed to elevated temperatures or other forms of stress [28].

\section{Proteins from Healthy Corn Seedlings}

Proteins associated exclusively with the healthy corn seedlings are presented in Table $\mathbf{3}$ along with their biological functions. These proteins were responsible for metabolism $(n=2)$, cell rescue, defense and virulence $(n=2)$, protein synthesis $(n=1)$, protein storage $(n=1)$, gene regulation $(n=1)$, cell fate and development $(n=2)$, interaction with environment $(n=1)$, binding function $(n=1)$, and cell cycle and DNA processing $(\mathrm{n}=1)$.

Chalcone-flavonone isomerase (spot 4) is involved in part of the biosynthetic pathway for all classes of flavonoids. It is responsible for the isomerization of tetrahydroxychalcone into naringenin. Flavonoids constitute a relatively diverse family of aromatic molecules that are derived from phenylalanine and malonyl-coenzyme A [29]. The glutathione S-transferase PM24 (spot 5) is reported from insects, plants, and microbes. It catalyzes nucleophilic attack by the thiolate anion of glutathione at electrophilic centers of hydrophobic molecules [30]. Proteins associated with chlorophyll biosynthesis, glutamate 1 semi-aldehyde aminotransferase (spot 8), and somatic protein storage, stem $31 \mathrm{kDa}$ glycoprotein (spot 9) were also present [31, 32]. Another protein was the nitrate reductase protein (spot 10) having key roles in the first step of nitrate assimilation in the plant fungi and bacteria [33]. The phytochrome B (spot 13) is the most abundant phytochrome in light-grown plants and it controls stem and petiole elongation, chloroplast development, and flowering time [34]. Lipoxygenase 1 (spot 18) is a member of enzyme lipoxygenases and is widely spread among plants. Lipoxygenases are differentially expressed in various tissues, depending on the growth stage and on physiological conditions. These enzymes catalyze the hydroperoxidation of polyunsaturated fatty acids leading to different primary and secondary oxidation products. Some of those products are involved in the physiological response to wounding and in pathogen resistance $[35,36]$. Other tentatively identified proteins were probable disease resistant protein (spot 19), RuBisCO subunit binding proteins beta sub unit (spot 20) and cell division cycle protein 48 homolog (spot 23) responsible for interaction with environment, protein binding function and cell cycle/DNA processing/cell fate, respectively [37-39].

\section{Up-Regulated and Down-Regulated Proteins from In- fested Seedlings}

Differentially expressed proteins in chinch bug-infested seedlings are presented with their functions in the plant sys-

Table 3. Proteins from Healthy Corn Seedlings with their Putative Functions

\begin{tabular}{|c|c|c|c|}
\hline Spot No. & Accession No. & Protein Name & Function \\
\hline 4 & P41088 & Chalcone-flavonone isomerase & Metabolism \\
\hline 5 & P46422 & Glutathione S transferase PM24 & Cell rescue, defense and virulence \\
\hline 8 & Q40147 & Glutamate 1 semi-aldehyde aminomutase & Protein synthesis \\
\hline 9 & P10743 & Stem 31 kDa glycoprotein & Storage protein \\
\hline 10 & P39871 & Nitrate reductase & Metabolism \\
\hline 13 & P93572 & Phytochrome B & Gene regulation \\
\hline 18 & $\mathrm{P} 37831$ & Lipoxygenase 1 & Cell fate/development/cell rescue, defense and virulence \\
\hline 19 & Q9LVT4 & Probable disease resistant protein At5g7250 & Interaction with environment \\
\hline 20 & Q43831 & RuBisCO subunit binding protein $\beta$ subunit & Protein with binding function \\
\hline 23 & P54774 & Cell division cycle protein 48 homolog & Cell cycle/DNA processing/cell fate \\
\hline
\end{tabular}


Table 4. Up-Regulated and Down-Regulated Proteins from Chinch Bug Infested Corn Seedlings with their Putative Functions

\begin{tabular}{|c|c|c|c|}
\hline \multicolumn{4}{|c|}{ Up-Regulated } \\
\hline 27 & P46750 & Protein disulfide-isomerase & Protein fate \\
\hline 28 & Q9FVT2 & Probable elongation factor 1-gamma 2 & Protein with binding function \\
\hline \multicolumn{4}{|c|}{ Down-Regulated } \\
\hline 22 & P27140 & Carbonic anhydrase & Metabolism \\
\hline 25 & P92981 & Adenylylsulfate reductase 2 & Metabolism \\
\hline 26 & P80608 & Cysteine Synthase & Metabolism \\
\hline
\end{tabular}

tem in Table 4. Five of the eight proteins were related to metabolism and one each to protein fate, protein binding and protein synthesis.

Some up-regulated proteins were those responsible for ATP production (spot 21), protein folding (spot 27), anchoring the complex to cellular components (spot 28) and biosynthesis of UDP-galactose (spot 29) [40-42]. The insect infestation might have initially induced the plant system to produce additional energy and structural substances. Among four down-regulated proteins, carbonic anhydrase (spot 22) catalyzes the reversible hydration of carbon dioxide to carbonic acids [43], and therefore may play a role in $\mathrm{pH}$ regulation. Adenylylsulfate reductase 2 (spot 25) and cysteine synthase (spot 26) are involved in the cysteine biosynthesis process $[42,44]$. The eukaryotic translation initiation factor $5 \mathrm{~A}$ (spot 31) is responsible in the formation of the first peptide bond in the process of protein synthesis [44]. Down regulation of these four proteins in infested seedlings indicates a reduced level of protein synthesis in infested seedlings.

\section{CONCLUSION}

To the best of our knowledge this is the first investigation on the interactions between chinch bugs and corn seedlings using 2-D gel electrophoresis and mass spectrometry. A large number of high quality protein spots were resolved in 2-D gels from both treatments. Though total number of proteins resolved in each gel did not differ much between treatments, the difference was still enough to explain the biological phenomenon associated with an abnormal appearance of corn seedlings. Presence of 13 and 10 different proteins in only infested seedlings and / or healthy seedling, and eight other differentially expressed proteins in infested corn seedlings enabled us to make inferences on the biological basis of abnormal appearance of the chinch bug infested corn seedlings. Proteins related to metabolism and defense formed a major group among the proteins detected from the infested seedlings showing that the infestation might have induced these proteins especially at the early stage of infestation. We also noticed up-regulation of some metabolic and structural proteins in the infested seedlings, and the down-regulation of proteins associated with protein synthesis and metabolism such as carbonic anhydrase, adenylylsulfate reductase and cysteine synthase.

With one exception, all of the proteins identified in the chinch bug - corn interaction seem to be activated within the plant system as a result of chinch bug-induced stresses such as osmotic stress, oxidative stress, acid stress, and wounding. A protein related to transcription, the DNA-directed RNA polymerase alpha chain, was present in the infested seedlings. The gene coding this protein has been found associated with the expression of some virulence genes within bacterial systems and possibly could be the only protein of chinch bug origin detected in this system. This ancestral chloroplast gene was present in Mesostigma viride, an earliest divergence and the most basal green plant lineage [45]. Future work to isolate, characterize, and localize this protein from the chinch bug is warranted. This study is important to understanding the signal mechanisms involved in chinch bug corn interaction and may lead to synthesis of molecular antagonists potentially useful in molecular breeding and exogenous applications. Protein profiles generated in this study contribute to existing corn protein databases and will serve as comparisons to those data generated during other perturbation studies in corn.

\section{ACKNOWLEDGEMENTS}

This research was supported by grants from the Life Sciences Biotechnology Institute, Mississippi State University. We are grateful to Dr. Frank M. Davis of Department of Entomology and Plant Pathology, Mississippi State University for his invaluable support during the implementation of the research program in the field and laboratory. This paper is Mississippi Agricultural and Forestry Experiment Station publication number J-11433.

\section{REFERENCES}

[1] Davis, F.M.; Williams, P.; Van Den Berg, J. Screening maize for resistance to chinch bug (Heteroptera: Lygaeidae) under greenhouse conditions. J. Econ. Entomol., 1996, 89, 1318-24.

[2] Negron, J.F.; Riley, T.J. Effect of chinch bug (Heteroptera: Lygaeidae) feeding in seedling field corn. J. Econ. Entomol., 1985, $78,1370-72$. 
[3] Flint, W.P. Chinch bug resistance shown by certain varieties of corn. J. Econ. Entomol., 1921, 14, 83-85.

[4] Holbert, J.R.; Flint, W.P.; Bigger, J.H. Chinch bug resistance in corn an inherited character. J. Econ. Entomol., 1934, 27, 121-24.

[5] Ritchie, S.W.; Hanway, J.J. How a corn plant develops. Iowa State Univ. Coop. Ext. Serv., 1982, Spec Rep 48.

[6] Hurkman, W.J.; Tanaka, C.K. Solubilization of plant membrane proteins for analysis by two-dimensional gel electrophoresis. Plant Physiol., 1986, 81, 802-6.

[7] Westermeier, R.; Naven, T. Proteomics in Practice, Wiley-VCH Verlag-GmbH: Weinheim, 2002, pp. 80-82.

[8] Porubleva, L.; Vander Velden, K.; Kothari, S.; Oliver, D.J.; Chitnis, P.R. The proteome of maize leaves: use of gene sequence and expressed sequence tag data for identification of protein with peptide mass fingerprints. Electrophoresis, 2001, 22, 1724-1738.

[9] Zörb, C.; Schmitt, S.; Neeb, A.; Karl, S.; Linder, M.; Schubert, S. The biochemical reaction of maize (Zea mays L.) to salt stress is characterized by a mitigation of symptoms and not by a specific adaptation. Plant Sci., 2004, 167, 91-100.

[10] Donnelly, B.E.; Madden, R.D.; Mitchener, M.M.; Porter, D.R.; Dillwith, J.W. Application of proteomics in characterizing aphid/plant interactions. Proceedings of the $89^{\text {th }}$ Annual Meeting American Entomological Society, Salt Lake City, USA, August 16, 2004; Entomological Society of America, USA, 2004; p. 70.

[11] Hajheidari, M.; Abdollahian-Noghabi, M.; Askari, H.; Heidari, M.; Sadeghian, S.Y.; Ober, E.S.; Salekdeh, G.S. Proteome analysis of sugar beet leaves under drought stress. Proteomics, 2005, 5, 95060.

[12] Weeks, M.E.; Sinclair, J.; Jacob, R.A.; Saxton, M.J.; Kirby, S.; Jones, J.; Waterfield, M.D.; Cramer, R.; Timms, J.F. Stress-induced changes in the Schizosaccharomyces pombe proteome using twodimensional difference gel electrophoresis, mass spectrometry and a novel integrated robotics platform. Proteomics, 2005, 5, 1669-85.

[13] Yan, S.; Tang, Z.; Su, W.; Sun, W. Proteomic analysis of salt stress-responsive proteins in rice root. Proteomics, 2005, 5, 235-44.

[14] Battey, N.H.; Dickinso, H.G.; Hetherington, A.M. In PostTranslational Modifications in Plants; Battey, N.H.; Dickinso, N.H.; Hetherington, H.G., Eds.; Cambridge University Press, UK, 1993; pp 1-16.

[15] Lonosky, P.M.; Zhang, X.; Honavar, V.G.; Dobbs, D.L.; Fu, A.; Rodermel, S.R. A proteomic analysis of maize chloroplast biogenesis. Plant Physiol., 2004, 134, 560-74.

[16] Lohrke, S.M.; Nechaev, S.; Yang, H.; Severinov, K.; Jin, S.J. Transcriptional activation of Agrobacterium tumefacience virulence gene promoters in Escherichia coli requires the A. tumefacience rpoA gene, encoding the Alpha subunit of RNA polymerase. $J$. Bacteriol., 1999, 181, 4533-39.

[17] Bricker, T.M.; Frankel, L.K. Structure and function of the $33 \mathrm{kDa}$ extrinsic protein of photosystem II. Photosynth. Res., 1998, 56, 157-73.

[18] Seidler, A. The extrinsic polypeptides of Photosystem II. Biochim. Biophys. Acta, 1996, 1277, 35-60.

[19] Kamiya, N.; Shen, J. Crystal structure of oxygen-evolving photosystem II from Thermosynechococcus vulcanus at 3.7- $\AA$ resolution. Proc. Natl. Acad. Sci. USA, 2003, 100, 98-103.

[20] Abbink, T.E.M.; Peart, J.R.; Mos, T.N.M.; Baulcombe, D.C.; Bol, J.F.; Linthorst, H.J. Silencing of a gene encoding a protein component of the oxygen-evolving complex of photosystem II enhances virus replication in plants. Virology, 2002, 295, 307-19.

[21] Halliwell, B.; Gutteridge, J.C.M. Free Radicals in Biology and Medicine, $3^{\text {rd }}$ Ed.; Oxford University Press: New York, 2000.

[22] Asada, K. Ascorbate peroxidase - a hydrogen peroxide - scavenging enzyme in plant. Physiol. Plant, 1992, 85, 235-41.

[23] Noctor, G.; Foyer, C.H. Ascorbate and glutathione: keeping active oxygen under control. Annu. Rev. Plant Physiol. Plant Mol. Biol., 1998, 49, 249-79.

[24] Katagiri, T.; Takahashi, S.; Shinizaki, K. Involvement of a novel Arabidopsis phospholipase D, AtPLD $\delta$, in dehydration-inducible accumulation of phosphatidic acid in stress signaling. Plant J., 2001, 26, 595-605.

[25] Massière, F.; Badet-Denisot, M.A. The mechanism of glutaminedependent amidotransferases. Cell Mol. Life Sci., 1998, 54, 205-22.

[26] Zalkin, H.; Smith, J.L. Enzymes utilizing glutamine as an amide donor. Adv. Enzymol. Relat. Areas Mol. Biol., 1998, 72, 87-144.
[27] Tenhaken, R.; Thulke, O. Cloning of an enzyme that synthesizes a key nucleotide-sugar precursor of hemicellulose biosynthesis from soybean: UDP-glucose dehydrogenase. Plant Physiol., 1996, 112, 1127-34.

[28] Borkovich, A.; Farrelly, F.W.; Finkelstein, D.B.; Taulien, J.; Lindquist, S. Hsp82 is an essential protein that is required in higher concentrations for growth of cell at higher temperatures. Mol. Cell Biol., 1989, 9, 3919-30.

[29] Winkel-Shirley, B. Flavonoid biosynthesis, a colorful model for genetics, biochemistry, cell biology, and biotechnology. Plant Physiol., 2001, 126, 485-93.

[30] Mannervick, B.; Danielson, U.H. Glutathione transferases - structure and catalytic activity. CRC Crit. Rev. Biochem., 1988, 23, 283337.

[31] Polking, G.F.; Hannapel, D.J.; Gladon, R.J. A cDNA clone for 5aminolevulinic acid dehydratase from tomato (Lycopersicon esculentum MILL). Plant Physiol., 1995, 107(3), 1033-34.

[32] Mason, H.S.; Guerrero, F.D.; Boyer, J.S.; Mullet, J.E. Protein homologous to leaf glycoproteins are abundant in stem of dark-grown soybean seedling - analysis of proteins and cDNAs. Plant Mol. Biol., 1988, 11, 845-56.

[33] Long, D.M.; Oaks, A. Rothstein S.J. Regulation of maize root nitrate reductase mRNA levels. Physiol. Plant., 1992, 8, 561-66.

[34] Reed, J.W.; Nagpal, P.; Poole, D.S.; Furuya, M.; Chory, J. Mutations in the gene for the red/far-red light receptor phytochrome B alter cell elongation and physiological responses throughout Arabidopsis development. Plant Cell, 1993, 5, 147-57.

[35] Malamy, J.; Klessig, D.F. Salicylic acid and plant disease resistance. Plant J., 1992, 2, 643-54.

[36] Mueller, M.J.; Broadschelm, W.; Spannagl, E.; Zenk, M.H. Signaling in the elicitation process is mediated through the octadecanoid pathway leading to jasmonic acid. Proc. Natl. Acad. Sci. USA, 1993, 90, 7490-94.

[37] Sato, S.; Nakamura, Y.; Kaneko, T.; Katoh, T.; Asamizu, E.; Kotani, H.; Tabata, S. Structural analysis of Arabidopsis thaliana chromosome 5. X. sequence features of the regions of 3,076,755 bp covered by sixty P1 and TAC clones. DNA Res., 2000, 7, 31-36.

[38] Schmitz, G.; Schmidt, M.; Feierabend, J. Comparison of the expression of a plastidic chaperonin 60 in different plant tissues and under photosynthetic and non-photosynthetic conditions. Planta, 1996, 200, 326-34.

[39] Shi, J.; Dixon, R.A.; Gonzales, R.A.; Kjellbom, P.; Bhattacharya, M.K. Identification of cDNA clones encoding valosin-containing proteins and other plant plasma membrane-associated proteins by a general immunoscreening strategy. Proc. Natl. Acad. Sci. USA, 1995, 92, 4457-61

[40] Kotani, H.; Nakamura, Y.; Sato, S.; Kaneko, T.; Asamizu, E.; Miyajima, N.; Tabata, S. Structural analysis of Arabidopsis thaliana chromosome 5. II. sequence features of the regions of 1,044,062 bp covered by thirteen physically assigned P1 clones. DNA Res., 1997, 4, 291-300.

[41] Li, C.P.; Larkins, B.A. Expression of protein disulfide isomerase is elevated in the endosperm of the maize floury-2 mutant. Plant Mol. Biol., 1996, 30, 873-82.

[42] Theologis, A.; Ecker, J.R.; Palm, C.J.; Federspiel, N.A.; Kaul, S.; White, O.; Alonso, J.; Altafi, H.; Araujo, R.; Bowman, C.L.; Brooks, S.Y.; Buehler, E.; Chan, A.; Chao, Q.; Chen, H.; Cheuk, R.F.; Chin, C.W.; Chung, M.K. Conn, L.; Conway, A.B.; Conway, A.R.; Creasy, T.H.; Dewar, K.; Dunn, P.; Etgu, P.; Feldblyum, T.V.; Feng, J.D.; Fong, B.; Fujii, C.Y.; Gill, J.E.; Goldsmith, A.D.; Haas, B.; Hansen, N.F.; Hughes, B.; Huizar, L.; Hunter, J.L.; Jenkins, J.; Johnson-Hopson, C.; Khan, S.; Khaykin, E.; Kim, C.J.; Koo, H.L.; Kremenetskaia, I.; Kurtz, D.B.; Kwan, A.; Lam, B.; Langin-Hooper, S.; Lee, A.; Lee, J.M.; Lenz, C.A.; Li, J.H.; Li, Y.P.; Lin, X.; Liu, S.X.; Liu, Z.A.; Luros, J.S.; Maiti, R.; Marziali, A.; Militscher, J.; Miranda, M.; Nguyen, M.; Nierman, W.C.; Osborne, B.I.; Pai, G.; Peterson, J.; Pham, P.K.; Rizzo, M.; Rooney, T.; Rowley, D.; Sakano, H.; Salzberg, S.L.; Schwartz, J.R.; Shinn, P.; Southwick, A.M.; Sun, H.; Tallon, L.J.; Tambunga, G.; Toriumi, M.J.; Town, C.D.; Utterback, T.; Van Aken, S.; Vaysberg, M.; Vysotskaia, V.S.; Walker, M.; Wu, D.; Yu, G.; Fraser, C.M.; Venter, J.C.; Davis, R.W. Sequence and analysis of chromosome 1 of the plant Arabidopsis thaliana. Nature, 2000, 408, 816-20.

[43] Sly, W.S.; Hu, P.Y. Human carbonic anhydrases and carbonic anhydrase deficiencies. Annu. Rev. Biochem. 1995, 64, 375-401. 
[44] Touzet, P.; Riccardi, F.; Morin, C.; Damerval, C.; Huet, J.C.; Pernollet, J.C.; Zivy, M.; de Vienne, D. The maize two-dimensional gel protein database: towards an integrated genome analysis program. Theor. Appl. Genet., 1996, 93, 997-1005.
[45] Lemieux, C.; Otis, C.; Turmel, M. Ancestral chloroplast genome in Mesostigma viride reveals an early branch of green plant evolution. Nature, 2000, 403, 649-52.

(C) Ghimire et al.; Licensee Bentham Open.

This is an open access article licensed under the terms of the Creative Commons Attribution Non-Commercial License (http://creativecommons.org/licenses/ by-nc/3.0/) which permits unrestricted, non-commercial use, distribution and reproduction in any medium, provided the work is properly cited. 